\title{
Equilibria and kinetics for $p H$-dependent axial ligation of alkyl(aquo) cobaloximes with aromatic and aliphatic N-donor ligands
}

\author{
V SRIDHAR, D SUDARSHAN REDDY, N RAVIKUMAR REDDY and \\ S SATYANARAYANA* \\ Department of Chemistry, Osmania University, Hyderabad 500007 , \\ India \\ e-mail: SSNSIRASANI@yahoo.com
}

MS received 18 May 2001; revised 10 October 2001

\begin{abstract}
Equilibria and kinetics of the reaction of bromomethyl(aquo) cobaloxime with histamine, histidine, glycine and ethyl glycine ester and iodomethyl(aquo) cobaloxime with cyanide, imidazole and substituted imidazoles were studied as a function of $p \mathrm{H}$ at $25^{\circ} \mathrm{C}, 1.0 \mathrm{M}$ ionic strength $(\mathrm{KCl})$ by spectrophotometry technique. The rate of substitution of $\mathrm{H}_{2} \mathrm{O}$ varies with the $p K a$ of the incoming ligand, thus establishing the existence of nucleophilic participation of the ligand in the transition state. Dissociation kinetic reactions were also studied as a function of $p \mathrm{H}$. Binding and kinetic data were interpreted based on the basicity, steric crowd of the entering ligand and HSAB principle. To compare the rate constants of the entering ligands $p \mathrm{H}$ independent second-order rate constants were calculated.
\end{abstract}

Keywords. Alkylcobaloximes; histamine; histidine; imidazoles; equilibrium constants.

\section{Introduction}

The key step in the mechanism of action of many enzymes, which require Vit- $\mathrm{B}_{12}$ coenzyme, is generally accepted as the homolytic cleavage of the $\mathrm{Co}-\mathrm{C}$ bond ${ }^{1-3}$. It is widely believed that structural and conformational changes in coenzyme $\mathrm{B}_{12}$ lead to acceleration in $\mathrm{Co}-\mathrm{C}$ bond cleavage rates ${ }^{4-6}$. The axial ligation reactions of metalloporphyrin ions in aqueous solution are dependent upon the particular metal ion ${ }^{7-12}$, equatorial ligands ${ }^{13}$ and the axial ligands ${ }^{14-18}$. The study of simple models of the $\mathrm{B}_{12}$ coenzyme, such as the cobaloximes, $\mathrm{RCo}(\mathrm{DH})_{2} \mathrm{~L}$, where $\mathrm{L}=$ neutral ligand and $\mathrm{R}=$ alkyl group, has furnished a significant amount of data ${ }^{19,20}$ that have provided a foundation for understanding the behaviour of cobalamins ${ }^{21}$. These cobaloximes have been the subject of extensive kinetic and mechanistic studies ${ }^{22,23}$. This activity has been motivated by the possibility that axial base release may be involved in biological mechanisms. Contrary to this, as models for coenzyme $\mathrm{B}_{12}$, cobaloximes can be faulted on a number of counts including electrochemical ${ }^{24}$, kinetic $^{25,26}$ and structural properties ${ }^{20,27,28}$. The $(\mathrm{DH})_{2}$ equatorial ligand system is not as electron donating as the corrin in coenzyme $\mathrm{B}_{12}$ or the

*For correspondence 
schiff-base equatorial ligands of other $\mathrm{B}_{12}$ models ${ }^{29}$. Compared to both cobalamins and other model systems, cobaloximes have stronger $\mathrm{Co}-\mathrm{C}$ bonds ${ }^{29}$ and shorter $\mathrm{Co}-\mathrm{L}$ ( $\mathrm{L}=$ pyridine or substituted pyridines) bonds ${ }^{20}$. Eldik et $a l^{30}$ studied the ligand substitution reactions of trans- $\left[\mathrm{Co}(\mathrm{en})_{2} \mathrm{Me}\left(\mathrm{H}_{2} \mathrm{O}\right)\right]^{2+}$ a simple model for coenzyme $\mathrm{B}_{12}$, with cyanide and imidazole as entering ligands and found that these ligands displace the coordinated water molecule trans to the methyl group and form the six coordinate complex. There is a need to study ligand substitution reactions trans to the axial alkyl ligand in coenzyme $\mathrm{B}_{12}$ and various model complexes. Since it is known that methyl cobaloximes and coenzyme $\mathrm{B}_{12}$ undergo substitution of their axial benzimidazole ligand with a protein histidine residues during complexation to the enzyme methionine synthase and methyl malonyl coenzyme A mutase, respectively ${ }^{31,32}$.

Since binding of cobaloximes with amino acids, imidazoles and histamine are more closely related to the structural and bonding characteristics of corrin systems involved in biological mechanisms, we decided to explore the kinetics and equilibria of the axial ligation of the alkyl(aquo)cobaloximes with the aromatic ligands imidazole, substituted imidazoles, histamine, histidine and aliphatic ligands (glycine, ethyl glycine ester).

\section{Materials and methods}

Histamine (histamine dihydrochloride), histidine (histidine monohydrochloride), glycine, ethyl glycine ester were obtained from Sigma and imidazole, 1-methyl imidazole, 2methyl imidazole, 2-ethyl imidazole, 1,2-di methyl imidazole were obtained from Acros. $\mathrm{KCl}$, HPLC grade methanol, acetic acid, $\mathrm{HCl}$, phosphoric acid, formic acid were obtained from Fluka. Dipotassium hydrogen phosphate, potassium dihydrogen phosphate, potassium phosphate, tris(hydroxymethyl)aminomethane (Tris), sodium acetate, potassium hydroxide were obtained from Acros. Double-distilled, deionized water was used throughout.

To maintain appropriate $p \mathrm{H} 0 \cdot 2 \mathrm{M}$ buffers of $\mathrm{HCl}(0-1 \cdot 5 p \mathrm{H}), \mathrm{KH}_{2} \mathrm{PO}_{4}$ and $\mathrm{H}_{3} \mathrm{PO}_{4}(2 \cdot 0$ $p \mathrm{H}), \mathrm{HCOOH}$ and $\mathrm{KOH}(2.5-3.0 p \mathrm{H}), \mathrm{CH}_{3} \mathrm{COOH}$ and $\mathrm{CH}_{3} \mathrm{COONa}(3.5-5.5 p \mathrm{H})$, $\mathrm{K}_{2} \mathrm{HPO}_{4}$ and $\mathrm{KH}_{2} \mathrm{PO}_{4}(6 \cdot 0-8.0 \mathrm{pH})$, Tris and $\mathrm{HCl}(8 \cdot 5-9.0 \mathrm{pH}), \mathrm{K}_{2} \mathrm{HPO}_{4}$ and $\mathrm{K}_{3} \mathrm{PO}_{4}(9 \cdot 5-$ $11.5 \mathrm{pH})$ were used.

Alkyl(aquo) cobaloximes were prepared by modified procedure of Brown et al ${ }^{33}$. All manipulations were performed under minimal illuminations due to photolability of the carbon-cobalt bond ${ }^{14}$. These alkyl(aquo) cobaloximes are photolabile, particularly in solution. Soluble in alcohols and DMSO, less so in chloroform or water and virtually insoluble in ether and hydrocarbon solvents.

$p \mathrm{H}$ values were determined with a Digisun digital $p \mathrm{H}$ meter equipped with a combined glass electrode. The electrode was standardized at two $p \mathrm{H}$ values $(p \mathrm{H}=4$ and 9.2) with standard buffer solutions. UV and visible spectra were recorded on a Hitachi U-3410, the sample compartment of which is provided with a thermostat and the concentrations of bromomethyl(aquo) cobaloximes $(0.00125 \mathrm{M})$ was fixed at $436 \mathrm{~nm}$ and iodomethyl(aquo) cobaloximes $(0.001 \mathrm{M})$ was fixed at $442 \mathrm{~nm}$. For axial ligation single wavelength measurements were made on an Elico single beam spectrophotometer SL 171 model. The sample compartment of which was thermostated at $25 \pm 0 \cdot 1^{\circ} \mathrm{C}$. 


\section{Results and discussion}

\subsection{Determination of dissociation constants of the ligands}

Values for the $p K a$ of the conjugate acid of ligands are obtained by potentiometric titration at $25 \pm 0 \cdot 1^{\circ} \mathrm{C}$. Values of $p K a$ 's are obtained by a linear least-squares fit of the data to (1) below, derived from (2), where $\alpha_{E}$ is the fraction of the total ligand present as the free base (or unprotonated) species as shown in (3).

$$
\begin{aligned}
p \mathrm{H} & =p K a+\log \left[\left(\boldsymbol{\alpha}_{\mathrm{E}}\right) /\left(1-\boldsymbol{\alpha}_{\mathrm{E}}\right)\right], \\
K a & =\left[L^{-}\right]\left[\mathrm{H}^{+}\right] /[H L], \\
\boldsymbol{\alpha}_{\mathrm{E}} & =K a /\left(K a+\left[\mathrm{H}^{+}\right]\right) .
\end{aligned}
$$

$K a$ is the dissociation constant of the ligand.

\subsection{Determination of equilibrium constants}

Apparent equilibrium constants ( $K_{\text {app }}$ values, see (4) below) for the axial ligation of alkyl(aquo) cobaloximes (scheme 1) were determined by spectrophotometric measurements. Solutions containing $\mathrm{RCo}(\mathrm{DH})_{2}\left(\mathrm{OH}_{2}\right)$, an appropriate buffer $(0 \cdot 2 \mathrm{M})$ to maintain $p \mathrm{H}, \mathrm{KCl}$ to maintain ionic strength $(1.0 \mathrm{M})$ and varying concentrations of ligand are taken in $3 \mathrm{~mm}$ cuvettes and allowed to equilibrate in a thermostated holder at $25 \pm 0 \cdot 1^{\circ} \mathrm{C}$ for $15 \mathrm{~min}$ prior to addition of cobaloxime.

$$
K_{\text {app }}=\frac{\left[\mathrm{RCo}(\mathrm{DH})_{2} \mathrm{~L}\right]}{\left[\mathrm{RCo}(\mathrm{DH})_{2} \mathrm{H}_{2} \mathrm{O}\right][\mathrm{L}]_{\text {free }}} .
$$

Final absorbance readings are taken after equilibrium is established as indicated by the time independence of the readings.

For such experimental setups, at a given $p \mathrm{H},(5)$ is applied as follows

$$
\Delta A=\Delta A_{\max }[L]_{f} /\left(1 / K_{\mathrm{app}}+[L]_{f}\right),
$$

where $\Delta A$ is the difference in absorbance between solutions containing cobaloxime and added ligand $(L)$ and solutions containing only cobaloxime at the same concentration, $\Delta A_{\max }$ is the maximum absorbance change thus obtained at high $[L]$, and $[L]_{f}$ is the

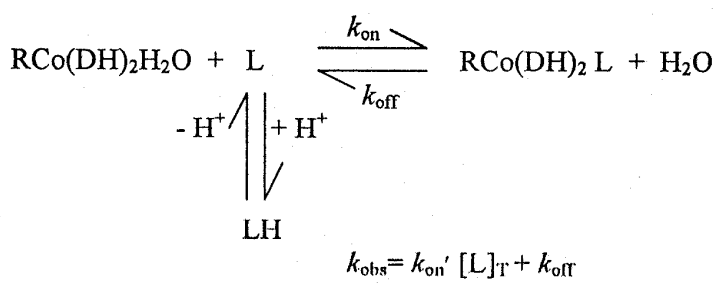

( $\mathrm{R}=\mathrm{BrCH}_{2}$ or $\mathrm{ICH}_{2}$ )

Scheme 1. 
equilibrium concentration of the ligand in both ionization states. The data are analysed by a least-squares fit to the rearranged form of (5) to give

$$
\begin{aligned}
& \Delta A=\Delta A_{\max }-\left\{1 / K_{\text {app }}\left(\Delta A /[L]_{f}\right)\right\}, \\
& {[L]_{f}=[L]_{T}-\left(C_{T} \Delta A / \Delta A_{\max }\right) .}
\end{aligned}
$$

$[L]_{f}$ is calculated from (7) using the measured value of $\Delta A_{\max },[L]_{T}$ is the total concentration of added ligand and $C_{T}$ is the total concentration of cobaloxime. Values of $K_{\text {app }}$ are obtained from the least-squares fit of (6) i.e., the plot of $\Delta A$ vs $\Delta A /[L]_{f}$ and the slope is $-1 / K_{\text {app. }}$.

The values for the equilibrium constants for axial ligation with respect to unprotonated ligand are calculated from the relation $K_{\mathrm{eq}}=K_{\mathrm{app}} / \alpha_{\mathrm{E}}$, where $\alpha_{\mathrm{E}}$ is calculated from (3).

\subsection{Determination of ligation rates $\left(k_{o n}\right)$}

For each ligand $L$, at various $p \mathrm{H}$ values, first-order rate constants $\left(k_{\mathrm{obs}}\right)$ are determined from the absorbance measurements at the same wavelength used for $K_{\text {app }}$ determinations under pseudo-first order condition with $L$ being, at least in 10-fold excess over cobaloxime concentration .

Reaction progress is monitored by measurements of the change in the absorbance upon addition of alkyl(aquo) cobaloxime to a $3 \mathrm{ml}$ cuvette, which contain $\mathrm{KCl}$ to maintain unit ionic strength, necessary buffer $(0.2 \mathrm{M})$ to maintain $p \mathrm{H}$ and ligand in the thermostated $\left(25 \pm 0 \cdot 1^{\circ} \mathrm{C}\right)$ cell compartment of Elico SL171 model. First order rate constants $\left(k_{\mathrm{obs}}\right)$ are obtained by least-squares fits of the data to (8) below

$$
\ln \left(A_{t}-A_{\infty}\right)=k_{\mathrm{obs}} t
$$

where $A_{t}$ is the absorbance at time $t$ and $A_{\infty}$ is the final absorbance.

Second-order rate constants, $k_{\mathrm{on}}$, at a given $\mathrm{pH}$ for a given ligand are obtained from the slopes of least-squares fits of the data,

$$
k_{\mathrm{obs}}=k_{\mathrm{on}}{ }^{\prime}[L]_{T}+k_{\mathrm{off}},
$$

where $[L]_{T}$ is the total concentration of $L$ present. Values of $k_{\text {on, }}$ the $p \mathrm{H}$ independent second-order ligation rate constant are calculated from $k_{\mathrm{on}}=k_{\mathrm{on}}{ }^{\prime} / \alpha_{\mathcal{L}}$, where $\alpha_{\mathrm{L}}$ is defined above.

\subsection{Determination of $k_{\text {off }}$}

Ligand dissociation rate constants, $k_{\text {off }}$ (scheme 1), are measured spectrophotometrically by addition of a small volume of a solution containing preformed $\mathrm{RCo}(\mathrm{DH})_{2} \mathrm{~L}$ to cuvettes containing $\mathrm{KCl}$ buffer $(0 \cdot 2 \mathrm{M})$ in the thermostated $\left(25 \pm 0 \cdot 1^{\circ} \mathrm{C}\right)$ cell compartment of the spectrophotometer .

Absorbance is continuously monitored at the same wavelength (436 nm or $442 \mathrm{~nm}$ ) used for $K_{\text {app }}$ and $k_{\mathrm{obs}}$ measurements. Triplicate measurements are made at each $p \mathrm{H}$ and first-order rate constants, $k_{\text {off }}$, are determined as above (8). In all cases, the ligand dissociation proceeds to $\geq 99 \%$ completion at both $p H s$. All plots of (8) are satisfactorily 
linear (correlation coefficients $\geq 0.998$ ). All determinations were averaged to obtain a final value of $k_{\text {off. }}$

Imidazole, substituted imidazoles, histamine, histidine, glycine, ethyl glycine ester undergo protonation of $\mathrm{N}$-atom with acid dissociation constants, $p K a$ in the range of 610. The values of the equilibrium constant $K_{\text {app }}$ for the reaction of the glycine, ethyl glycine ester, histidine and histamine with bromomethyl cobaloximes and $K_{\text {app }}$ values for the reaction of imidazole and substituted imidazoles with iodomethyl cobaloximes are given in table 1. Logarithmic plots of $\log K_{\text {app }} \mathrm{vs} p \mathrm{H}$ are shown in figure 1 which indicates that as the $p \mathrm{H}$ increases the $K_{\text {app }}$ increases and the affinity for ligands increases in the order Glyest $<$ Gly $<$ Hisamn $<$ Hisdn for bromomethyl(aquo) cobaloxime and 2Etimd $<1,2$-diMeimd $<$-Meimd $<$ Imd $<1$-Meimd $<<\mathrm{CN}^{-}$for iodomethyl (aquo) cobaloxime. If we compare the $p \mathrm{H}$ dependent binding plots of glycine and ethyl glycine ester in both cases $K_{\text {app }}$ increases with increase in $p \mathrm{H}$ and after certain $p \mathrm{H}$ they become $p \mathrm{H}$ independent, glycine shows $p \mathrm{H}$ dependence up to $10 p \mathrm{H}$ and later becomes $p \mathrm{H}$ independent, whereas ethyl glycine ester binding is $p \mathrm{H}$ dependent up to $8 \mathrm{pH}$ and later becomes $p \mathrm{H}$ independent. The binding of histidine to bromomethyl(aquo) cobaloxime has been shown in figure 2.

The equilibrium constants for the ligation of $\mathrm{ICH}_{2} \mathrm{Co}(\mathrm{DH})_{2} \mathrm{OH}_{2}$ by imidazole, substituted imidazoles and $\mathrm{CN}^{-}$is also dependent upon the $p K a$ values of the ligands. In case of imidazole and 1-meimidazole the $\mathrm{pH}$ dependent binding constants are measured from $p \mathrm{H} 5.0$ to 8.5 , which demonstrate the $p \mathrm{H}$ dependent and $p \mathrm{H}$ independent binding of these ligands to $\mathrm{ICH}_{2} \mathrm{Co}(\mathrm{DH})_{2} \mathrm{OH}_{2}$, whereas in case of 2-Meimd, 2-Etimd and 1,2 Dimeimd, the binding constants cannot be measured below $p \mathrm{H} 6.5$ as they bind weakly to $\mathrm{Co}$ (III) of cobaloxime. If we compare the binding constants of various ligands with $\mathrm{ICH}_{2} \mathrm{Co}(\mathrm{DH})_{2} \mathrm{OH}_{2}$ they are in the order $K_{\mathrm{CN}}{ }^{-}>K_{1-\text { Meimd }}>K_{\text {Imd }}>K_{2-\text { Meimd }}>$

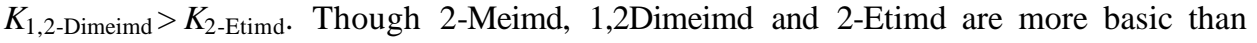

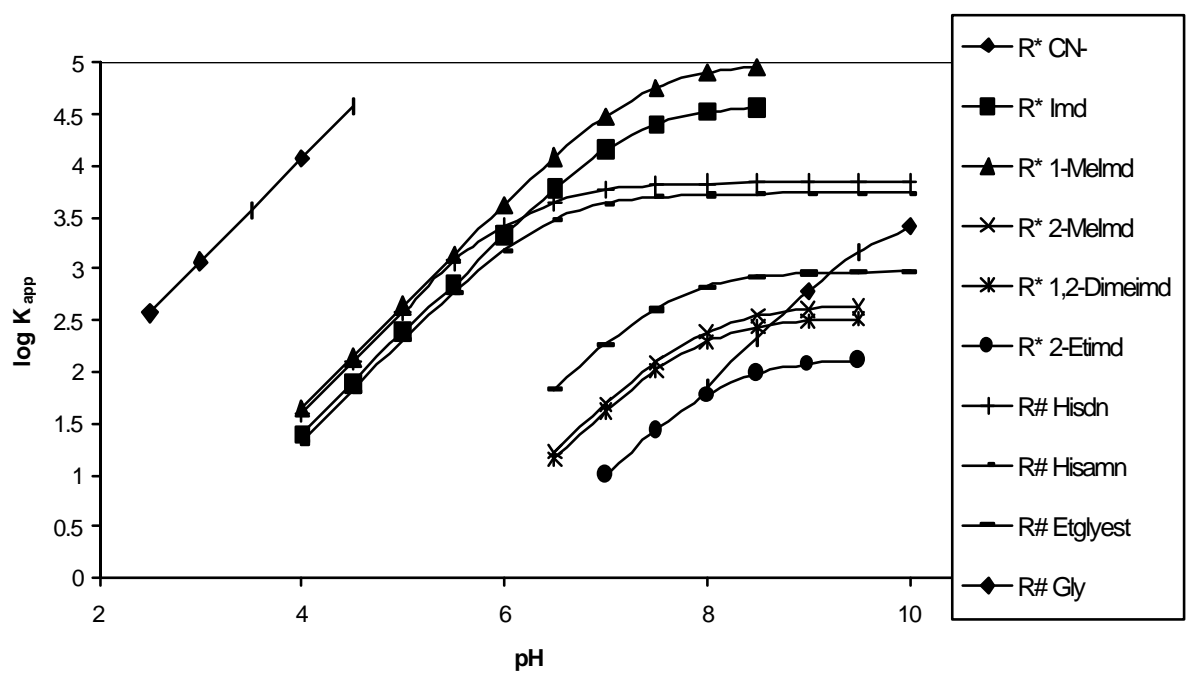

Figure 1. Dependence of $\log K_{\text {app }}$ on $p \mathrm{H}$ for the axial ligation of $\mathrm{RCo}(\mathrm{DH})_{2} \mathrm{OH}_{2}$ by different ligands at $25^{\circ} \mathrm{C}\left(\mathrm{R}^{*}\right.$ - ligation with $\mathrm{ICH}_{2}$ complex; $\mathrm{R}^{\#}$ - ligation with $\mathrm{BrCH}_{2}$ complex). 


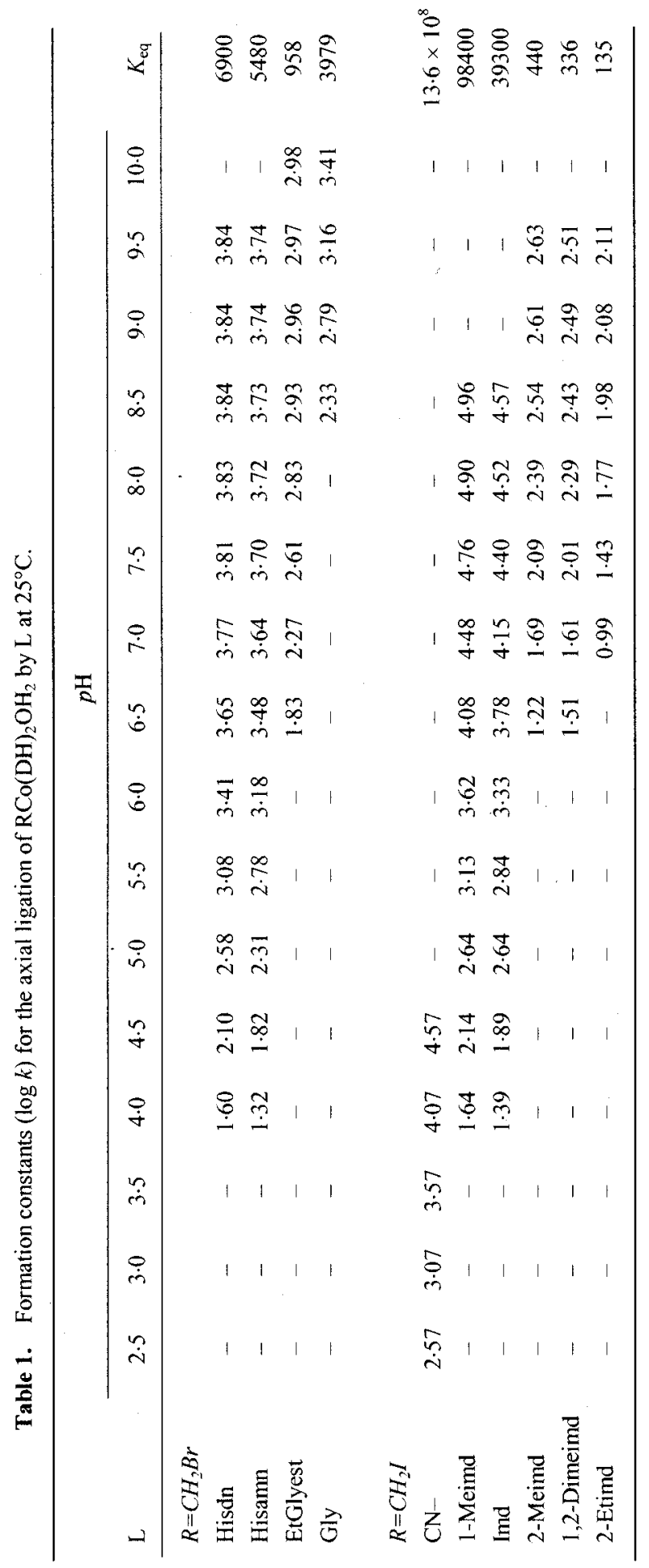




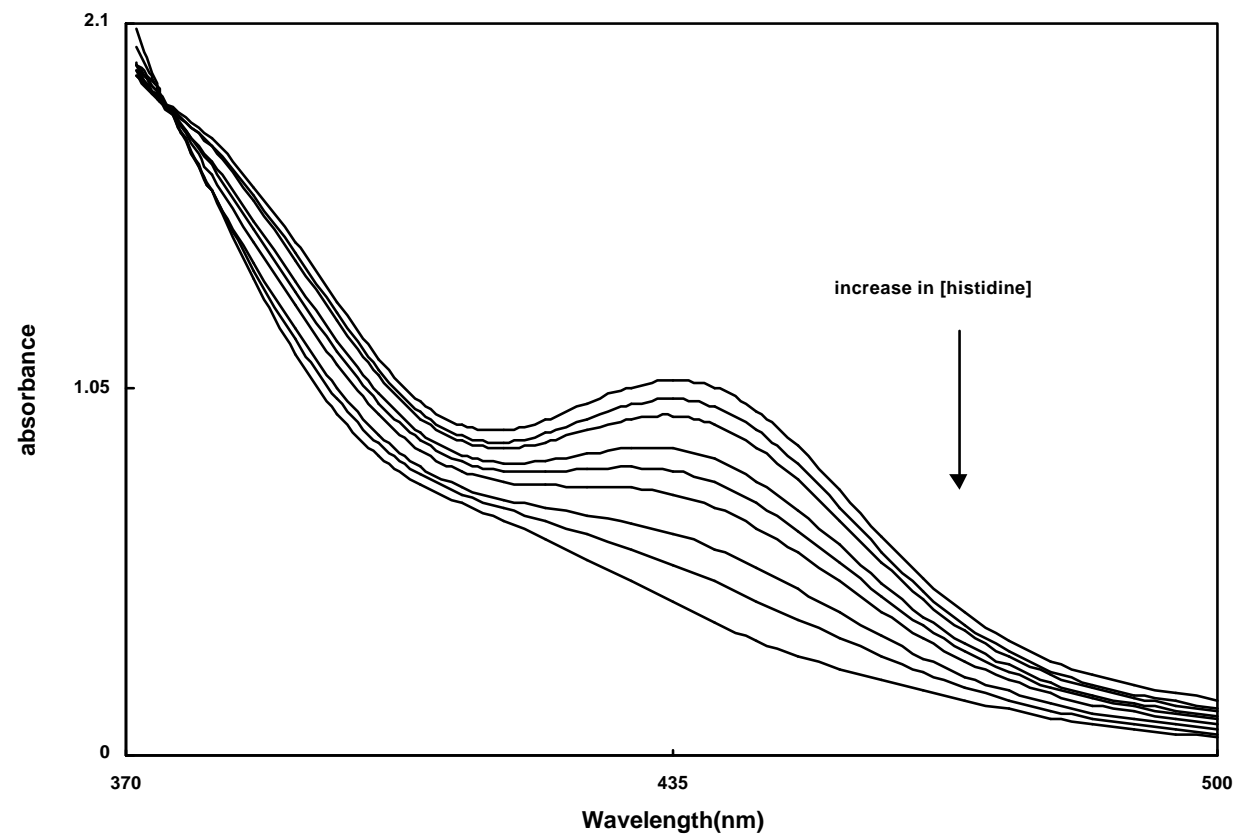

Figure 2. Binding of $\mathrm{BrCH}_{2} \mathrm{Co}(\mathrm{DH})_{2} \mathrm{OH}_{2}$ with varying concentrations of histidine at $p \mathrm{H}=7.5$ and $25^{\circ} \mathrm{C}$, isosbestic point $=380 \mathrm{~nm}$.

Hisdn and Imd, they form less stable complexes. This is due to steric hindrance caused by the methyl or ethyl at the $\mathrm{C}_{2}$ of imidazole. Similar trends are observed ${ }^{34}$ in the study of $\left[\mathrm{CNCo}(\mathrm{DH})_{2} \mathrm{~L}\right]$ (where $L=2$-substituted imidazoles) and in the binding of $P(n \text {-but })_{3}$ to cobaloximes ${ }^{35}$. Though the $P$ in $P(n \text {-but })_{3}$ is soft and more basic than imidazoles it binds weakly, this indicates that steric hindrance plays a dominant role.

In the case of histamine and histidine there is no increase in $K_{\text {app }}$ at the $p \mathrm{H}$ above the $p K a$ of the ligand. This clearly indicates that in these ligands the binding is through the endocyclic nitrogen. If it binds through $\mathrm{NH}_{2}$ group at higher $p \mathrm{H}$, there should be an increase in $K_{\text {app }}$ even at higher $p \mathrm{H}$. With histidine, the coordination is through the nitrogen of the imidazole ring, though there is a possibility of $\mathrm{COO}^{-}$and $\mathrm{NH}_{2}$ coordination, the $\mathrm{NH}_{2}$ is mostly protonated below $8.0 \mathrm{pH}$, hence not available for binding.

A soft or class b character has been assigned to cobaloximes (III) ${ }^{36}$ and is consistent with the observed greater ligand affinity of cyanide, imidazole ${ }^{37,38}$, histidine or histamine than the hard glycine or ethyl glycine ester. Furthermore, softness appears to be related to the ability of a cobalt complex to stabilize a $\mathrm{Co}-\mathrm{C}$ bond. $\mathrm{Co}(\mathrm{III})$ to ligand $\pi$ bonding is used to explain the reverse order for the dependence of ligation strength upon ligand basicity. The order of $\mathrm{RCo}(\mathrm{DH})_{2} \mathrm{~L}$ stability is attributed to the ability of imidazoles or histidine or histamine to accept electrons into higher energy unfilled $\pi^{*}$ anti bonding orbitals through $\mathrm{d} \pi \rightarrow p \pi$ back bonding, whereas primary amine (glycine or ethyl glycine ester) cannot accept electrons in either fashion. The reverse order for the dependence of $\mathrm{RCo}(\mathrm{DH})_{2} \mathrm{~L}$ stability on ligand basicity among two series of ligands, aromatic (histamine, histidine, imidazole and substituted imidazoles) and aliphatic (glycine and ethyl glycine ester) is not unexpected based on the following reasons. 
(1) An increase in basicity is associated with increased ability for $\sigma$ donation for example glycine form more stable complexes than ethyl glycine ester, since glycine is more basic ( $p K a$ 9.74) than ethyl glycine ester ( $p K a 7 \cdot 62)$.

(2) An increase in basicity is associated with decreased ability for the aromatic ligands to function as $\pi$ acceptors.

The values of $K_{\mathrm{Hisdn}}>K_{\mathrm{Hisamn}}$, though histamine is slightly more basic than histidine. Histidine and histamine bind to $\mathrm{Co}(\mathrm{III})$, via $\mathrm{N} \rightarrow \mathrm{Co}(\mathrm{III})$ donor as well as $\mathrm{Co}(\mathrm{III}) \rightarrow \mathrm{N} \pi$ bond. Histidine is a better $\pi$ acceptor than histamine, hence histidine forms more stable complexes than histamine.

The plot of pseudo first-order rate constant $k_{\text {obs }}$ against histidine, histamine or imidazole concentration is linear with a very small intercept, which may indicate that a small dissociation is accompanied by the complex formation (figure 3 ). This appears to be more likely at lower $p \mathrm{H}$ (i.e. much below the $p K_{\mathrm{a}}$ of imidazole, histidine or histamine) this is probably due to the protonation of ligand. The kinetic studies cannot be taken at high $p \mathrm{H}$ by conventional methods due to fast reactions. This is supposed by the observed high binding constant values at high $p \mathrm{H}$. In case of histidine and histamine, as the $p \mathrm{H}$ is increased the rate of formation of complex increases. In case of histamine there is not much change in the $k_{\mathrm{obs}}$ even the $p \mathrm{H}$ is increased up to $7.0 \mathrm{pH}$. In both the cases, as the $p \mathrm{H}$ is decreased from $4.0 \mathrm{pH}$ initially the rate of dissociation is constant but after reaching $2.5 \mathrm{pH}$ there is a sudden increase in the dissociation rate constant. That means the bound histamine or histidine comes out from the complex at lower $p \mathrm{H}$ easily. This supports the very low binding constant at lower $p \mathrm{H}$ and high binding constant at higher $p \mathrm{H}$ (table 1).

The plots of $k_{\mathrm{obs}}$ vs concentration of glycine and ethyl glycine ester give straight lines with non-zero intercepts. The rate of dissociation $\left(k_{\text {off }}\right)$ increases with decreasing $p \mathrm{H}$ (figure 4). For glycine the plot of $k_{\mathrm{obs}} \mathrm{vs} p \mathrm{H}$ increases with $p \mathrm{H}$ linearly. Whereas in case of ethyl glycine ester it is sigmoidal that is from $p \mathrm{H} 7$ to 8 it increases slowly and then increases suddenly from 8 to $8 \cdot 5$, after which it is steady and there is no change in the $k_{\text {obs }}$ with increase in $p \mathrm{H}$. This can be explained that at high $p \mathrm{H}$ it reaches saturation, it means there is no effect of $p \mathrm{H}$ on the rate of formation (table 2).

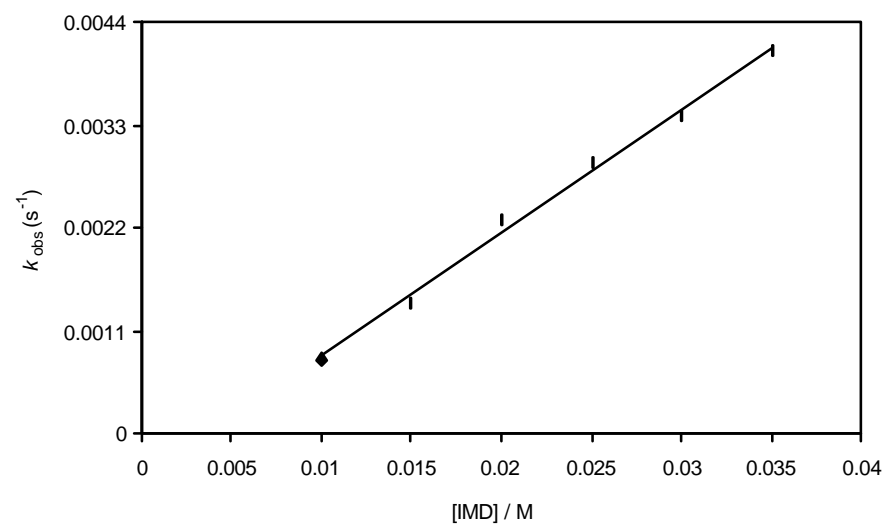

Figure 3. Dependence of [IMD] on pseudo first-order rate constants, $k_{\mathrm{obs}}$, for the formation of $\mathrm{ICH}_{2} \mathrm{Co}(\mathrm{DH})_{2} \mathrm{IMD}$ at $p \mathrm{H}=5$ and $25^{\circ} \mathrm{C}$, the gradient $k_{\mathrm{on}}{ }^{\prime}=$ $0.132 \mathrm{dm}^{3} \mathrm{~mol}^{-1} \mathrm{~s}^{-1}$. 


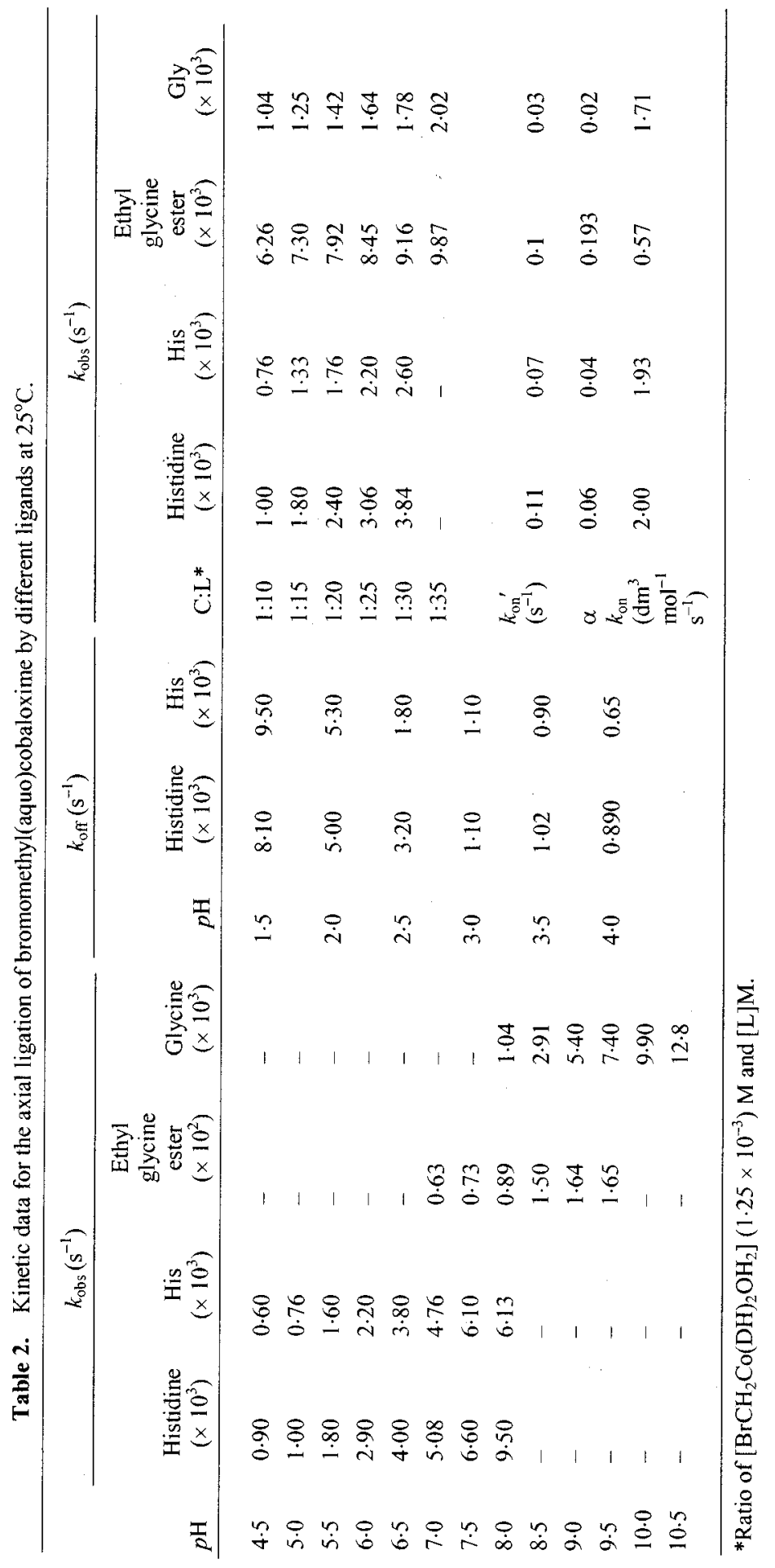




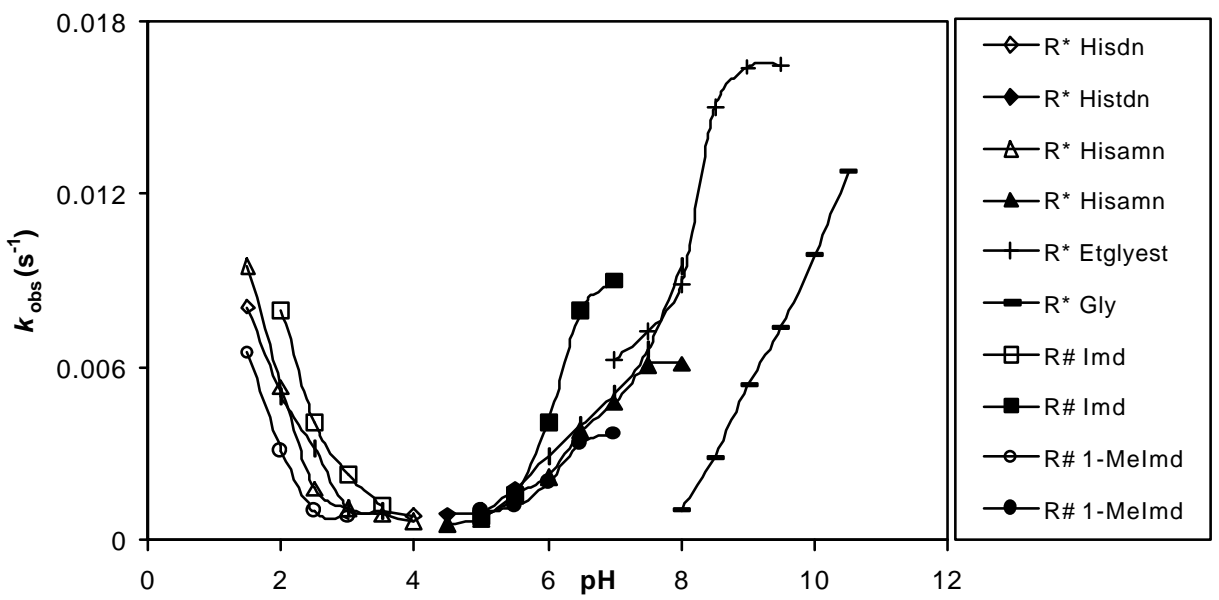

Figure 4. Dependence of $k_{\text {obs }}$ on $p \mathrm{H}$ for the axial ligation of $\left[\mathrm{RCo}(\mathrm{DH})_{2} \mathrm{OH}_{2}\right]$ and dependence of $k_{\text {off }}$ on $p \mathrm{H}$ for the dissociation of $L$ from $\left[\mathrm{RCo}(\mathrm{DH})_{2} \mathrm{~L}\right]$ complex at $25^{\circ} \mathrm{C}$. $\left(\mathrm{R}^{*}-\mathrm{BrCH}_{2} ; \mathrm{R}^{\#}-\mathrm{ICH}_{2}\right)$.

Figure 4 shows the pseudo first-order rate constants for the formation $\left(k_{\mathrm{obs}}\right)$ and dissociation $\left(k_{\mathrm{off}}\right)$ as a function of $p \mathrm{H}$ (table 3 ). For Imd $k_{\mathrm{obs}}$ increases slowly up to $3.5 p \mathrm{H}$ and then there is a sharp rise. For $\mathrm{CN}^{-}$there is a slow increase between 1.0 and $1.5 \mathrm{pH}$ then rises sharply between 2.0 and $3.0 \mathrm{pH}$. Later it is steady and there is not much increase in $k_{\text {obs }}$ with increase in $p \mathrm{H}$. These kinetic data are supported by binding data. The rate of dissociation of Imd and $\mathrm{CN}^{-}$trans to the $\left[\mathrm{ICH}_{2} \mathrm{Co}(\mathrm{DH})_{2} \mathrm{~L}\right]$ complex increases with decrease in $p \mathrm{H}$. Imidazole can be removed completely at $p \mathrm{H} 2.0$ whereas $\mathrm{CN}^{-}$is removed at $0.0 \mathrm{pH}$. This also supports the fact that $\mathrm{CN}^{-}$binds more strongly than imidazole.

The kinetics of substitution of the axial base in alkylcobaloximes and related cobalt complexes has been studied under a variety of conditions ${ }^{39,40}$. In none of the studies was the mechanism established conclusively although in all cases strong evidence was provided that the intimate mechanism is dissociative (Id or D).

In coordinating solvents 'pentacoordinate' species are formed involving pentacoordinate alkylcobalt complexes and solvent. In view of the evidence presented above for the existence of pentacoordinate alkylcobaloximes and the ligation kinetic studies of others, both on alkyl cobalt complexes with other equatorial ligand system ${ }^{41}$ and on cobaloxime(III) complexes ${ }^{42,43}$, an $\mathrm{SN}^{1}$ mechanism appears to be operative.

The small dependence of $k_{\text {on }}$ upon ligand basicity within each series of ligands is clearly related to the fact that while the reacting complex is a soft acid the ligand is hard. The rate constants are better correlated with the relative softness of the ligand among the ligands we have studied.

The small difference in the rate of ligand substitution despite large differences in the stabilities of the $\mathrm{Co}(\mathrm{III})$ complexes $^{44}$ and aquo cobalamine have been taken to indicate the lack of significant activation of the transition state by the incoming ligand and, conversely, domination of the transition state activation by the leaving ligand (i.e., a dissociative interchange mechanism Id) ${ }^{45}$. The stability of pentacoordinate alkyl cobalt complexes and the evidence that both the dominant soft $\mathrm{Co}(\mathrm{III})$ complexes, 


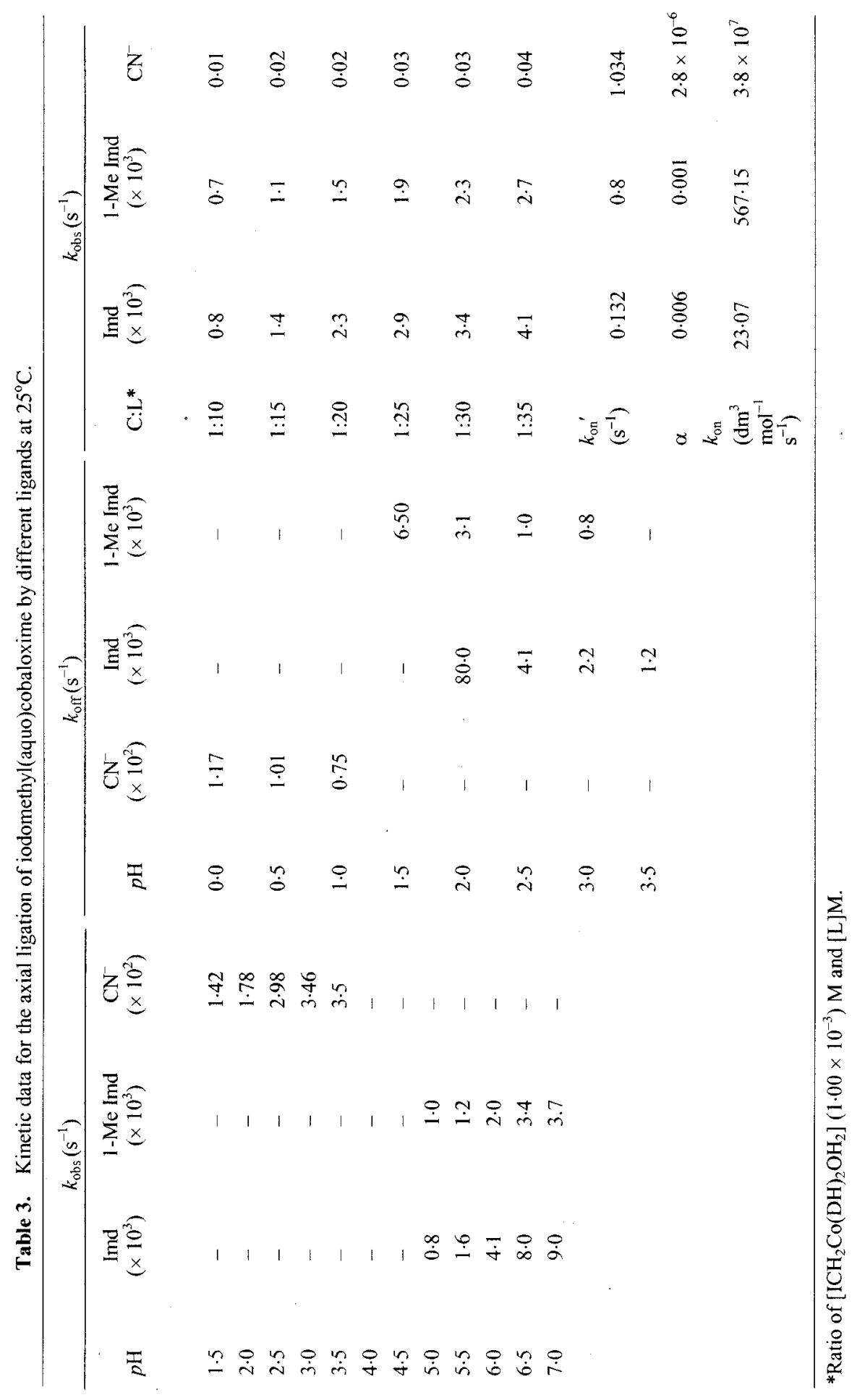


$\left[\mathrm{Co}(\mathrm{CN})_{5} \mathrm{H}_{2} \mathrm{O}\right]^{2-}$ and $\left[\mathrm{Co}\left(\mathrm{NH}_{3}\right)_{5} \mathrm{SO}_{3}\right]^{+}$, undergo $\mathrm{SN}^{1}$ ligand substitution reactions ${ }^{46,47}$, clearly favor this mechanism for the ligation reaction of $\mathrm{BrCH}_{2} \mathrm{Co}(\mathrm{DH})_{2} \mathrm{OH}_{2}$. The coordination between the softness of a cobalt(III) complex and the stability of its pentacoordinate species permits $\mathrm{SN}^{1}$ mechanism for ligand substitution ${ }^{48}$.

To compare the rate constants of the various ligands for the formation of complex with $\mathrm{BrCH}_{2} \mathrm{Co}(\mathrm{DH})_{2} \mathrm{OH}_{2}$ and $\mathrm{ICH}_{2} \mathrm{Co}(\mathrm{DH})_{2} \mathrm{OH}_{2}$, we have calculated the second order rate constant, $k_{\text {on }}^{\prime}$ from the slopes of the pseudo first-order rate constants as a function of concentration of the ligand. Since this is also $p \mathrm{H}$-dependent for better comparison we have calculated $k_{\mathrm{on}}$, the $p \mathrm{H}$ independent second-order rate constant. The order of $k_{\mathrm{on}}$ is as follows: $\quad \mathrm{CN}^{-}>>1$-Meimd ${ }^{28}>$ Imd $>$ Hisdn $>$ Hisamn $>$ Gly $>$ Etglyest. This is in accordance with the basicity order of the ligands. Though the basicity of glycine and ethyl glycine ester are larger than imidazole, histidine or histamine $k_{\text {on }}$ are much smaller. But within glycine and ethyl glycine ester again they follow the basicity order, $k_{\text {on }}$ of glycine > ethyl glycine ester. This can be explained based on $\pi$ bonding and HSAB principle.

\section{Conclusions}

In the ligation reaction of $\mathrm{BrCH}_{2} \mathrm{Co}(\mathrm{DH})_{2} \mathrm{OH}_{2}$ and $\mathrm{ICH}_{2} \mathrm{Co}(\mathrm{DH})_{2} \mathrm{OH}_{2}$ the $\pi$-accepting ligands (cyanide, imidazole, histidine or histamine) react more rapidly than the purely $\sigma$ donors (glycine or ethyl glycine ester). The greater reactivities of the cyanide, imidazole, histidine and histamine compound to glycine or ethyl glycine ester are discussed based on the basicity, $\mathrm{d} \pi-p \pi$ back bonding and HSAB principle. From these studies we also found that there is severe steric strain between substituent at the $\mathrm{C}_{2}$ of a coordinated imidazole and the cobaloxime.

\section{Acknowledgements}

We gratefully acknowledge the University Grants Commission, New Delhi for financial support.

\section{References}

1. Toraya T, Krodel E, Mildran A S and Abeles R H 1979 Biochemistry 18417

2. Abeles R H and Dolphin D 1976 Acc. Chem. Res. 9114

3. Halpern J 1974 Ann. NY. Acad. Sci. 2239

4. Dolphin D (ed.) $1982 B_{12}$ (New York: Wiley) vol. 2

5. Pratt J M 1985 Chem. Soc. Rev. 161

6. Hay B P and Finke R G 1987 J. Am. Chem. Soc. 1098012

7. Ashley K R 1976 J. Inorg. Nucl. Chem. 39357

8. Ashley K R and Leipoldt G J 1981 Inorg. Chem. 202326

9. Leipoldt G J, Van Eldik R and Kelm H 1983 Inorg. Chem. 224146

10. Fleischer E B and KrishnaMurthy M 1971 J. Am. Chem. Soc. 933784

11. KrishnaMurthy M 1977 Inorg. Chim. Acta 25215

12. Ashley K R, Shyu S and Leipoldt G J 1980 Inorg. Chem. 191613

13. Choo P L, Mulichak A M, Jones R W Jr., Bacon J W and Pett V B 1990 Inorg. Chim. Acta 171 183

14. Brown K L and Kallen R G 1972 J. Am. Chem. Soc. 941894

15. Brown K L, Lyles D, Pencovici M and Kallen R G 1975 J. Am. Chem. Soc. 977338

16. Brown K L and Satyanarayana S 1992 Inorg. Chim. Acta 201113

17. Hirota S, Kosugi E, Marzilli L G and Yamauchi O 1998 Inorg. Chim. Acta 27590 
18. Rajeshwar Rao A, Sridhar V and Satyanarayana S 1999 Proc. Natl. Acad. Sci. India A69 1

19. Randaccio L, Bresciani-Pahor N, Zangardo E and Marzilli L G 1989 Chem. Soc. Rev. 16229

20. Bresciani-Pahor N, Forcolin M, Marzilli L G, Randaccio L, Summers M F and Toscano P J 1985 Coord. Chem. Rev. 631

21. Kim S H, Chen H L, Feilchenfeild N and Halpern J 1988 J. Am. Chem. Soc. 1103120

22. Crumbliss A L and Wilmarth W K 1970 J. Am. Chem. Soc. 922593

23. Trogler W C, Stewart R C and Marzilli L G 1974 J. Am. Chem. Soc. 963641

24. Elliot C M, Hershenhart E, Finke R G, Smith B L 1981 J. Am. Chem. Soc. 1035558

25. Parker W O Jr, Bresciani-Pahor N, Zangrando E, Randaccio L and Marzilli L G 1985 Inorg. Chem. 243908

26. Reenstra W W and Jencks W P 1979 J. Am. Chem. Soc. 1015780

27. Summers M F, Marzilli L G, Bresciani-Pahor N and Randaccio L 1984 J. Am. Chem. Soc.106 4478.

28. Rossi M, Glusker J P, Randaccio L, Summers M F, Toscano P J and MarzilliLG 1985J.Am. Chem. Soc. 1071729

29. Halpern J 1983 J. Pure Appl. Chem. 553677

30. Mohamed S A Hamza, Carlos Ducker-Benfer and Rudi Van Eldik 2000 Inorg. Chem. 393777

31. Drennan C L, Huang S, Drummond J T, Mathews R G and Ludwig M C 1994 Sciences 206 2669

32. Manica F, Keep N H, Nakagawa A, Leadlay P F, Mc Swerney S, Ramussen B, Bosake P, Diat O and Evans P R 1996 Structure 4229

33. Brown K L 1986 Organometallic syntheses (eds) R B King and J J Eisch (Amsterdam: Elsevier) vol 3, p 186

34. Marques H M, Egan T J, Marsh J H, Mellor J R and Munro O Q 1989 Inorg. Chim. Acta 166 249

35. Frederick R J and Ronald C K 1975 J. Am. Chem. Soc. 975820

36. Hague D N and Halpern J 1967 J. Inorg. Chem. 62059

37. Sridhar V and Satyanarayana S 2000 Proc. Indian Acad. Sci. (Chem. Sci.) 112579

38. Sridhar V and Satyanarayana S 2001 Indian J. Chem A40 165

39. Poon C K 1973 Coord. Chem. Rev. 101

40. Herlinger A W and Brown T L 1972 J. Am. Chem. Soc. 94388

41. Costa G, Mestroni G, Tauzher G, Goddall D M and Hill H A O 1970 Chem. Commun. 34

42. Earley J E and Zimmerman J G 1972 Inorg. Nucl. Chem. Lett. 8687

43. Zsako J, Finta Z and Varhelyl C S 1972 J. Inorg. Nucl. Chem. 342887

44. Eigen M and Wilkins R G 1965 Adv. Chem. Ser. No. 4

45. Longford D H and Gray H B 1965 Ligand substitution processes (ed.) A Benjamin (New York: )

46. Haim A J, Grassi R J and Wilmarth W K 1965 Adv. Chem. Ser. No. 49

47. Halpern J, Palmer R A and Blakley L M 1966 J. Am. Chem. Soc. 882877

48. Firth R A, Hill H A O, Pratt J M, Thorp R G and Williams R J 1969 J. Chem. Soc. A 381 